\title{
SINTERING BEHAVIOR AND MICROWAVE DIELECTRIC PROPERTIES OF NOVEL LOW TEMPERATURE FIRING $\mathrm{Bi}_{3} \mathrm{FeMo}_{2} \mathrm{O}_{12}$ CERAMIC
}

\author{
DI ZHOU*, ${ }^{*}$, LI-XIA PANG ${ }^{\dagger}$, JING GUO $^{*}$, , YING WU ${ }^{* *}$, \\ GAO-QUN ZHANG**, HONG WANG*** and XI YAO** \\ *Electronic Materials Research Laboratory \\ Key Laboratory of the Ministry of Education \\ $X i$ an Jiaotong University, Xi' an 710049, P. R. China \\ ${ }^{\dagger}$ Laboratory of Thin Film Techniques and Optical Test \\ $X i$ an Technological University, Xi' an 710032, P. R. China \\ *International Center for Dielectric Research \\ $X i$ an Jiaotong University, Xi' an 710049, P. R. China \\ \$zhoudi1220@gmail.com
}

Received 15 June 2011

Revised 25 August 2011

\begin{abstract}
In the present work, a novel low temperature firing $\mathrm{Bi}_{3} \mathrm{FeMo}_{2} \mathrm{O}_{12}$ ceramic was synthesized via the solid-state reaction method. The monoclinic $\mathrm{Bi}_{3} \mathrm{FeMo}_{2} \mathrm{O}_{12}$ phase can be formed at a low temperature $670^{\circ} \mathrm{C}$. A relative density above $96 \%$ can be obtained when sintering temperature is above $800^{\circ} \mathrm{C}$. The $\mathrm{Bi}_{3} \mathrm{FeMo}_{2} \mathrm{O}_{12}$ ceramic sintered at $845^{\circ} \mathrm{C}$ for $2 \mathrm{~h}$ shows high microwave dielectric performance with a permittivity $\sim 27.2$, a $Q f$ value of $14,500 \mathrm{GHz}$ and a temperature coefficient of $-80 \mathrm{ppm} /{ }^{\circ} \mathrm{C}$. It might be a candidate for low temperature co-fired ceramics technology.
\end{abstract}

Keywords: Microwave dielectric; low-temperature co-fired ceramic (LTCC); bismuth molybdate.

\section{Introduction}

Low temperature co-fired ceramics (LTCC) technology has played an important role in the fabrication of modern wireless communication devices due to its advantage in the high integration, miniaturization and reliability. The LTCC technology required microwave dielectric ceramics with a series of dielectric permittivities, high quality factor $(Q f$, where $Q=1 /$ dielectric loss and $f=$ resonant frequency), near zero temperature coefficient $\left(\mathrm{TCF}=0 \mathrm{ppm} /{ }^{\circ} \mathrm{C}\right)$ and lower sintering temperature than the melting points (M.P.) of common electrode materials, such as silver $\left(\right.$ M.P. $\left.=961^{\circ} \mathrm{C}\right)$, copper $\left(\right.$ M.P. $\left.=1084^{\circ} \mathrm{C}\right)$, etc. $^{1,2}$

Addition of low melting point oxides $\left(\mathrm{B}_{2} \mathrm{O}_{3}\right.$, $\mathrm{CuO}, \mathrm{V}_{2} \mathrm{O}_{5}$, etc.) or low softening glasses $\left(\mathrm{B}_{2} \mathrm{O}_{3}-\right.$ $\mathrm{ZnO}, \mathrm{B}_{2} \mathrm{O}_{3}-\mathrm{CuO}$, etc.) is the most common method to lower the sintering temperature of microwave dielectric ceramics because that it is simple and effective. ${ }^{3-6}$ However, the addition usually deteriorated the $Q f$ value of microwave dielectric ceramics. In recent ten years, a novel method to search for the

$\S_{\text {Corresponding author. }}$ 
microwave dielectric ceramics with intrinsic low sintering temperatures from the low-melting-point-oxides rich systems has attracted much attention. ${ }^{7-10}$ In our previous work, it was found that in the $\mathrm{Bi}_{2} \mathrm{O}_{3}-$ $\mathrm{MoO}_{3}$ binary system, there exist many ultra-lowtemperature-firing single-phase ceramics with high microwave dielectric performance, such as $\mathrm{Bi}_{2} \mathrm{Mo}_{2} \mathrm{O}_{9}$ with a permittivity of 38 , a $Q f$ value of $12,500 \mathrm{GHz}$, a TCF of $+31 \mathrm{ppm} /{ }^{\circ} \mathrm{C}$ and a sintering temperature around $620^{\circ} \mathrm{C}$, etc. ${ }^{8-10}$ The molybdenum polyhedral framework was found to influence the sintering temperature seriously. ${ }^{9}$ In the present work, the search for new microwave dielectric ceramics with intrinsic low sintering temperatures was extended into the ternary system $\mathrm{Bi}_{2} \mathrm{O}_{3}-\mathrm{MoO}_{3}-\mathrm{Fe}_{2} \mathrm{O}_{3}$. The only reported single-phase $\mathrm{Bi}_{3} \mathrm{FeMo}_{2} \mathrm{O}_{12}$ ceramic was synthesized via the solid-state reaction method. The sintering behavior, microstructure and microwave dielectric properties were studied.

\section{Experimental Procedure}

Proportionate amounts of reagent-grade starting materials of $\mathrm{Bi}_{2} \mathrm{O}_{3}$ (>99\%, Shu-Du Powders Co. Ltd., Chengdu, China), $\mathrm{Fe}_{2} \mathrm{O}_{3}$ (>99\%, Guo-Yao Co, Ltd., Shanghai, China) and $\mathrm{MoO}_{3}$ (>99\%, Fuchen Chemical Reagents, Tianjin, China) were prepared according to the stoichiometric formulation $\mathrm{Bi}_{3} \mathrm{FeMo}_{2} \mathrm{O}_{12}$ compositions. Powders were mixed and milled for $4 \mathrm{~h}$ using a planetary mill (Nanjing Machine Factory, Nanjing, China) by setting the running speed at $150 \mathrm{rpm}$ with the Yttria Stabilized Zirconia (2 $\mathrm{mm}$ in diameter) milling media. The mixed oxides were then calcined at $570^{\circ} \mathrm{C}$ and $670^{\circ} \mathrm{C}$ for $4 \mathrm{~h}$. After being crushed and remilled for $5 \mathrm{~h}$ using the $\mathrm{ZrO}_{2}$ milling media and deionized water, powders were pressed into cylinders (10 $\mathrm{mm}$ in diameter and $5 \mathrm{~mm}$ in height) in a steel die with $5 \mathrm{wt} \%$ PVA binder addition under a uniaxial pressure of $200 \mathrm{MPa}$. Samples were sintered in the temperature range from $600^{\circ} \mathrm{C}$ to $680^{\circ} \mathrm{C}$ for $2 \mathrm{~h}$.

The crystalline structures of samples were investigated using $\mathrm{X}$-ray diffraction with $\mathrm{Cu} \mathrm{K} \alpha$ radiation (Rigaku D/MAX-2400 X-ray diffractometer, Tokyo, Japan). Microstructures of sintered ceramic were observed on the as-fired surface and fractured surfaces with scanning electron microscopy (SEM) (JSM-6460, JEOL, Tokyo, Japan). The apparent densities of sintered ceramics were measured by Archimedes' method. Dielectric behaviors at microwave frequency were measured with the $\mathrm{TE}_{01 \delta}$ shielded cavity method with a network analyzer (8720ES, Agilent, Palo Alto, CA) and a temperature chamber (Delta 9023, Delta Design, Poway, CA). The temperature coefficient of resonant frequency $\tau_{f}$ (TCF) was calculated with the following formula:

$$
\tau_{f}=\frac{f_{85}-f_{25}}{f_{25} \times(85-25)},
$$

where $f_{85}$ and $f_{25}$ were the $\mathrm{TE}_{01 \delta}$ resonant frequencies at $85^{\circ} \mathrm{C}$ and $25^{\circ} \mathrm{C}$, respectively.

\section{Results and Discussion}

The X-ray diffraction patterns for $\mathrm{Bi}_{3} \mathrm{FeMo}_{2} \mathrm{O}_{12}$ compound calcined and sintered at different temperatures for $4 \mathrm{~h}$ are shown in Fig. 1. For sample calcined at $570^{\circ} \mathrm{C}$ for $4 \mathrm{~h}$, main phase of $\mathrm{Bi}_{2} \mathrm{MoO}_{6}$ was formed, and peaks of $\mathrm{Bi}_{2} \mathrm{Mo}_{3} \mathrm{O}_{12}$ and $\mathrm{Bi}_{3}$ $\mathrm{FeMo}_{2} \mathrm{O}_{12}$ phases could also be observed, which means that the designed phase $\mathrm{Bi}_{3} \mathrm{FeMo}_{2} \mathrm{O}_{12}$ is started to be formed. When calcinations temperature increases to $670^{\circ} \mathrm{C}$, almost all the XRD peaks could be indexed as a pure $\mathrm{Bi}_{3} \mathrm{FeMo}_{2} \mathrm{O}_{12}$ phase besides a minor peak at $27.5^{\circ}$, which remains even when the temperature increases to $770^{\circ} \mathrm{C}$ and it might belong to the high temperature phase of $\mathrm{Bi}_{2} \mathrm{MoO}_{6}$. The $\mathrm{Bi}_{3} \mathrm{FeMo}_{2} \mathrm{O}_{12}$ phase was first synthesized by Sleight and Jeitschko ${ }^{11}$ in 1974 and it represented the first example of trivalent cation on the tetrahedral sites of the $\mathrm{CaWO}_{4}$ type scheelite

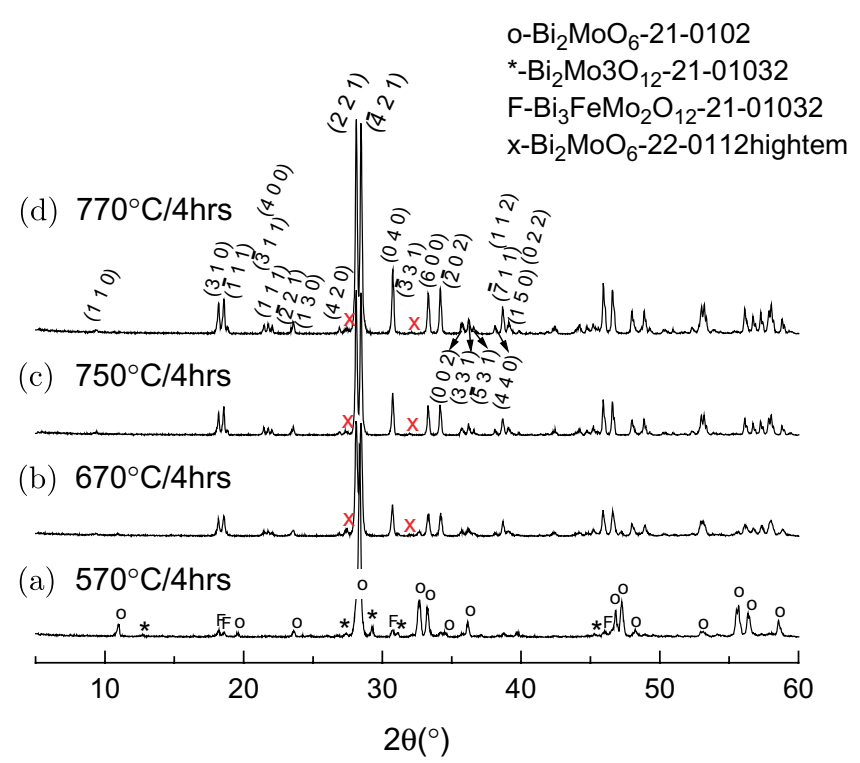

Fig. 1. X-ray diffraction patterns of the $\mathrm{Bi}_{3} \mathrm{FeMo}_{2} \mathrm{O}_{12}$ composition calcined at (a) $570^{\circ} \mathrm{C}$ for $4 \mathrm{~h}$ and (b) $670^{\circ} \mathrm{C}$ for $4 \mathrm{~h}$; sintered at (c) $750^{\circ} \mathrm{C}$ for $2 \mathrm{~h}$ and $(\mathrm{d}) 770^{\circ} \mathrm{C}$ for $2 \mathrm{~h}$. 
structure, in which the $\mathrm{FeO}_{4}$ and $\mathrm{MoO}_{4}$ tetrahedra can take on an ordered arrangement. The XRD data here can be well indexed with a space group $\mathrm{C} 2 / \mathrm{c}$ with the cell parameters $a=16.127 \AA, b=11.631 \AA$, $c=5.254 \AA$ and $\beta=90.855^{\circ}$, which is in agreement with Jeitschko et al.'s results. ${ }^{12}$ The ternary $\mathrm{Bi}-\mathrm{Fe}-\mathrm{Mo}-\mathrm{O}$ system was well known as glass composition exhibiting low melting temperature. ${ }^{13}$ The $\mathrm{Bi}_{3} \mathrm{FeMo}_{2} \mathrm{O}_{12}$ composition is just at the boundary of crystal phases formation region and glass formation region in the $\mathrm{Bi}-\mathrm{Fe}-\mathrm{Mo}-\mathrm{O}$ system. Although the glasses were reported to be obtained by fast cooling of melts in this system, ${ }^{13}$ the existence of additional $\mathrm{Bi}_{2} \mathrm{MoO}_{6}$-like phase might be caused by the formation of little amorphous $\mathrm{Bi}-\mathrm{Fe}-\mathrm{Mo}-\mathrm{O}$ glasses, which cannot be detected by the XRD technology.

The bulk density and relative density of $\mathrm{Bi}_{3} \mathrm{FeMo}_{2} \mathrm{O}_{12}$ ceramic as a function of sintering temperature are shown in Fig. 2. It is seen that as sintering temperature increased from $770^{\circ} \mathrm{C}$ to $800^{\circ} \mathrm{C}$, the bulk density of $\mathrm{Bi}_{3} \mathrm{FeMo}_{2} \mathrm{O}_{12}$ ceramic increased from $6.79 \mathrm{~g} / \mathrm{cm}^{3}$ to about $6.89 \mathrm{~g} / \mathrm{cm}^{3}$ and reached saturated at around $830^{\circ} \mathrm{C}$. The theoretical density calculated from the XRD patterns was $7.164 \mathrm{~g} / \mathrm{cm}^{3}$, which is similar to the literature's reports. ${ }^{11,12}$ As seen from Fig. 2, the relative density reached about $96 \%$ when sintering temperature was above $800^{\circ} \mathrm{C}$, which means that the $\mathrm{Bi}_{3} \mathrm{FeMo}_{2} \mathrm{O}_{12}$ ceramic can be well densified at a relative low temperature about $800^{\circ} \mathrm{C}$.

The SEM photo of as-fired surface of $\mathrm{Bi}_{3} \mathrm{FeMo}_{2} \mathrm{O}_{12}$ ceramic sintered at $830^{\circ} \mathrm{C}$ for $2 \mathrm{~h}$ is shown in Fig. 3 . Dense and homogenous microstructure is revealed,

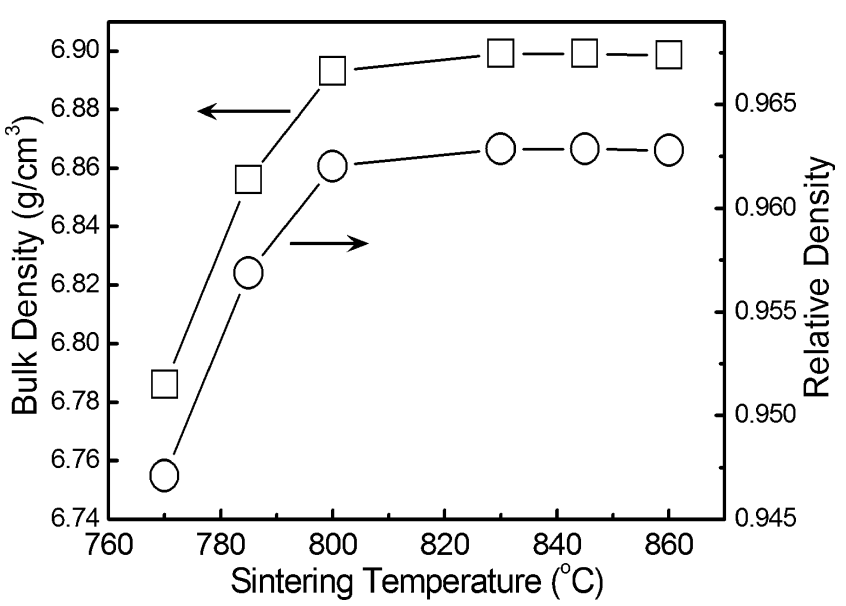

Fig. 2. Bulk density and relative density of $\mathrm{Bi}_{3} \mathrm{FeMo}_{2} \mathrm{O}_{12}$ ceramic as a function of sintering temperature.

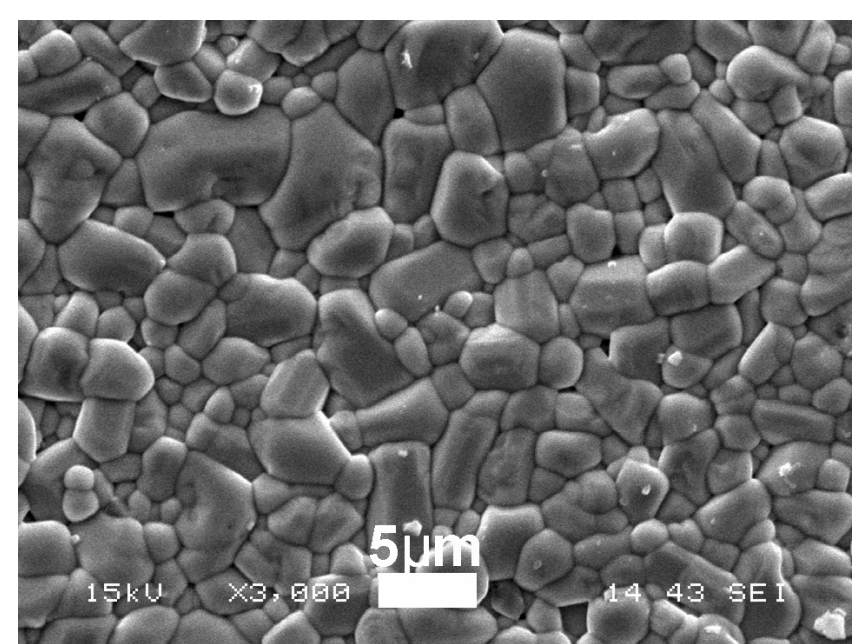

Fig. 3. SEM photo of as-fired surface of $\mathrm{Bi}_{3} \mathrm{FeMo}_{2} \mathrm{O}_{12}$ ceramic sintered at $830^{\circ} \mathrm{C}$ for $2 \mathrm{~h}$.

which indicates that the $\mathrm{Bi}_{3} \mathrm{FeMo}_{2} \mathrm{O}_{12}$ ceramic can be well densified at $830^{\circ} \mathrm{C}$. The grains show a polygonal shape and grains sizes distribute between $1 \sim 5 \mu \mathrm{m}$. There is no evidence of liquid-sintering observed and it confirms that the $\mathrm{Bi}_{3} \mathrm{FeMo}_{2} \mathrm{O}_{12}$ ceramic has a low intrinsic sintering temperature.

Microwave dielectric relative permittivity and $Q f$ value of $\mathrm{Bi}_{3} \mathrm{FeMo}_{2} \mathrm{O}_{12}$ ceramic measured at $\sim 6.9 \mathrm{GHz}$ are shown in Fig. 4 as a function of sintering temperature. As the sintering temperature increases, microwave dielectric permittivity increases first along with the elimination of the pores and then reaches a saturated value at sintering temperature $\geq 830^{\circ} \mathrm{C}$. With the further increase of sintering temperature, the permittivity usually decreases slightly before melting due to the

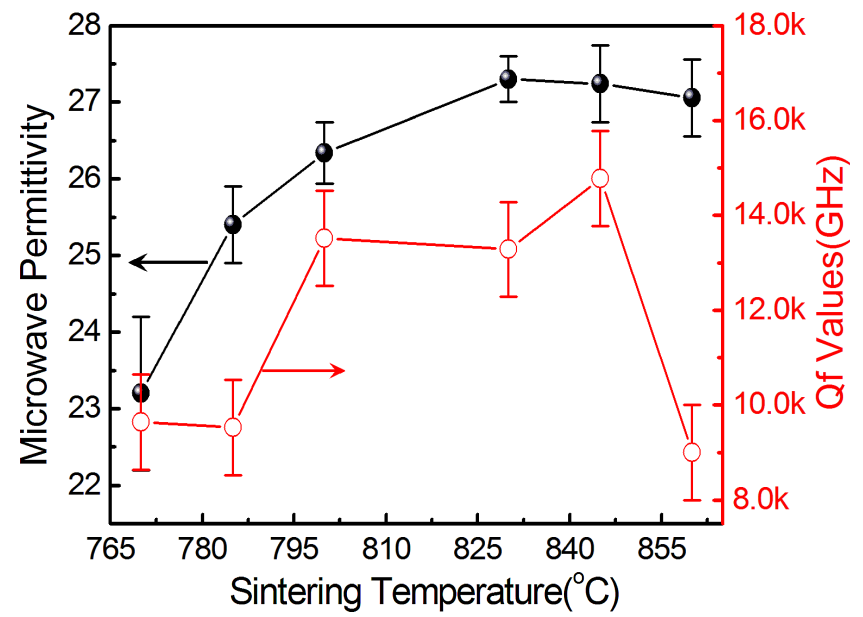

Fig. 4. Microwave dielectric properties of $\mathrm{Bi}_{3} \mathrm{FeMo}_{2} \mathrm{O}_{12}$ ceramics as a function of sintering temperature. 
secondary grain growth. The $Q f$ value of microwave dielectric ceramic is usually determined by the intrinsic and extrinsic dielectric losses. The extrinsic loss is influenced by many defects, such as grain boundaries, pores, etc. ${ }^{14,15}$ Hence, for a microwave dielectric ceramic, the high $Q f$ values can only be achieved at a narrow sintering temperature, at which the influence of defects is minimized. The best microwave dielectric properties was obtained in $\mathrm{Bi}_{3} \mathrm{FeMo}_{2} \mathrm{O}_{12}$ ceramic sample sintered at $860^{\circ} \mathrm{C}$ for $2 \mathrm{~h}$ with a permittivity $\sim 27.2$, a $Q f$ value of $14,500 \mathrm{GHz}$ and a temperature coefficient of $-80 \mathrm{ppm} /{ }^{\circ} \mathrm{C}$.

\section{Conclusion}

A pure $\mathrm{Bi}_{3} \mathrm{FeMo}_{2} \mathrm{O}_{12}$ phase can be formed at $670^{\circ} \mathrm{C}$ via a solid-state reaction method. The $\mathrm{Bi}_{3} \mathrm{FeMo}_{2} \mathrm{O}_{12}$ ceramic can be well densified at $830^{\circ} \mathrm{C}$ with grain size lying between 1 and $5 \mu \mathrm{m}$ and a relative density above $96 \%$. The best microwave dielectric properties was obtained in $\mathrm{Bi}_{3} \mathrm{FeMo}_{2} \mathrm{O}_{12}$ ceramic sample sintered at $845^{\circ} \mathrm{C}$ for $2 \mathrm{~h}$ with a permittivity $\sim 27.2$, a $Q f$ value of $14,500 \mathrm{GHz}$ and a temperature coefficient of $-80 \mathrm{ppm} /{ }^{\circ} \mathrm{C}$. It might be a candidate for LTCC technology.

\section{Acknowledgments}

This work was supported by the National 973Project of China (2009CB623302), National Project of International Science and Technology Collaboration
(2009DFA51820) and also the NSFC projects of China (109790365, 60871044, and 50835007).

\section{References}

1. M. T. Sebastian and H. Jantunen, Int. Mater. Rev. 53, 57 (2008).

2. I. M. Reaney, J. Am. Ceram. Soc. 89, 2063 (2006).

3. D. Zhou, H. Wang and X. Yao, Mater. Chem. Phys. 104, 397 (2007).

4. D. Zhou, H. Wang, X. Yao and Y. Liu, J. Electroceram. 21, 469 (2008).

5. H. Jantunen, R. Rautioaho, A. Uusimaki and S. Leppavuori, J. Eur. Ceram. Soc. 20, 2331 (2000).

6. C. L. Huang, R. J. Lin and J. H. Wang, Jpn. J. Appl. Phys. 41, 758 (2002).

7. D. K. Kwon, M. T. Lanagan and T. R. Shrout, J. Am. Ceram. Soc. 88, 3419 (2005).

8. D. Zhou, H. Wang, X. Yao and L. X. Pang, J. Am. Ceram. Soc. 91, 3419 (2008).

9. D. Zhou, H. Wang, L. X. Pang, C. A. Randall and X. Yao, J. Am. Ceram. Soc. 92, 2242 (2009).

10. D. Zhou, C. A. Randall, H. Wang, L. X. Pang and X. Yao, J. Am. Ceram. Soc. 93, 1096 (2010).

11. A. W. Sleight and W. Jeitschko, Mater. Res. Bull. 9, 951 (1974).

12. W. Jeitschko, A. W. Sleight, W. R. Mcclellan and J. F. Weiher, Acta Crystallogr. B 32, 1163 (1976).

13. R. Iordanova, Y. Dimitriev, V. Dimitrov, S. Kassabov and D. Klissurski, J. Non-Cryst. Solids 231, 227 (1998).

14. S. J. Penn, N. McN. Alford, A. Templeton, X. Wang, M. Xu, M. Reece and K. Schrapel, J. Am. Ceram. Soc. 80, 1885 (1997).

15. D. Zhou, L. X. Pang, X. Yao and H. Wang, Mater. Chem. Phys. 115, 126 (2009). 